\title{
PENINGKATAN KETERAMPILAN BERCERITA JURU PELIHARA SITUS SEJARAH MADIUN MELALUI METODE BERCERITA BERPASANGAN
}

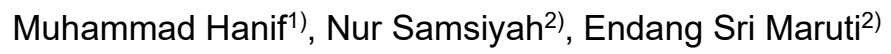 \\ 1)Prodi PIPS Program Pascasarjana, Universitas PGRI Madiun, Madiun, Jawa Timur, Indonesia \\ 2)PGSD, FKIP, Universitas PGRI Madiun, Madiun, Jawa Timur, Indonesia \\ Corresponding author :Endang Sri Maruti \\ E-mail : marutiendang@gmail.com
}

\section{Diterima 18 Agustus 2020, Direvisi 6 September 2020, Disetujui 10 September 2020}

\begin{abstract}
ABSTRAK
Situs sejarah banyak mengandung cerita dan peninggalan sejarah, untuk itu situs dan peninggalan sejarah perlu dipelihara dan dilestarikan. Pemeliharaan dan pelestarian situs dan peninggalan sejarah perlu partisipasi banyak pihak, salah satunya yaitu dengan melibatkan para juru pelihara atau juru kunci. Pada umumnya juru pelihara maupun juru kunci memiliki dedikasi yang luar biasa dalam menjaga, merawat, dan memilihara situsnya. Tujuan kegiatan ini adalah untuk meningkatkan keterampilan para juru pelihara situs dalam bercerita tentang situs sejarah yang dipeliharanya melalui metode bercerita berpasangan. Kegiatan pelatihan diikuti oleh 11 juru kunci dari 11 situs sejarah di Madiun. Kegiatan pelatihan bercerita sejarah bagi para juru pelihara, meliputi (1) sosialisasi program, (2) pengayaan situs peninggalan sejarah Madiun, (3) pendalaman teknik bercerita secara ilmiah dan menarik, (4) pembagian kelompok selanjutnya pengkajian situs sejarah, (5) pertukaran informasi dengan saling berpasangan, (6) penceritaan kembali informasi yang diperoleh dari pasangannya di depan seluruh juru pelihara situs. Hasil pelatihan menunjukkan bahwa ada peningkatan keterampilan berkomunikasi terutama dalam hal kemampuan bercerita sejarah para juru pelihara situs, cerita sejarah menjadi tidak membosankan, dan cerita menarik untuk disimak. Peningkatan keterampilan itu juga berdampak pada peningkatan jumlah pengunjung situs.
\end{abstract}

Kata kunci: situs sejarah; juru pelihara; keterampilan bercerita sejarah; metode cerita berpasangan.

\begin{abstract}
Historical sites contain a lot of stories and historical relics, for that sites and historical relics need to be preserved and preserved. The maintenance and preservation of sites and historical relics requires the participation of many parties, one of which is by involving caretakers or caretakers. In general, caretakers and caretakers have extraordinary dedication in maintaining, maintaining and maintaining the site. The purpose of this activity is to improve the skills of site maintainers in telling stories about historical sites that they maintain through the pair storytelling method. The training activity was attended by 11 caretakers from 11 historical sites in Madiun. Historical storytelling training activities for carers, including (1) socialization of the program, (2) enrichment of Madiun's historical heritage sites, (3) deepening of scientific and interesting storytelling techniques, (4) group division and further study of historical sites, (5) exchange information in pairs, (6) retelling of information obtained from their partners in front of all site maintainers. The results of the training show that there is an increase in communication skills, especially in the ability to tell the history of the site maintainers, historical stories are not boring, and interesting stories to listen to. Increasing those skills also has an impact on increasing the number of site visitors.
\end{abstract}

Keywords: historical sites; caretakers; historical storytelling skills; the pair story method.

\section{PENDAHULUAN}

Madiun (Kabupaten dan Kota) banyak memiliki cerita sejarah, baik sejarah Jawa maupun sejarah Indonesia. Sejak peradaban Hindu-Budha sampai jaman kemerdekakan, banyak peristiwa berlatar di Madiun, sehingga di wilayah ini ditemui tempat atau area yang di dalamnya ada peninggalan sejarah (situs sejarah).

Makna situs sejarah (sie histiry) menunjuk pada tempat, area, wilayah ditemukan peninggalan-peninggalan manusia di masa yang lalu (Haviland, 1985). Suroto (2020) juga menyampaikan bahwa situs merupakan tempat, lokasi, atau titik terjadinya 
sebuah peristiwa, atau lokasi spasial tempat berdirinya struktur yang sudah jadi atau sedang direncanakan, atau lokasi berdirinya sekumpulan struktur, seperti: bangunan, kota, atau monumen. Hal serupa diutarakan Alderson\&Low (1996) bahwa situs merupakan tempat peninggalan-peninggalan atau jejak (reliccs/traces) bagian dari budaya yang dilestarikan karena memiliki nilai historis. Peninggalan-peninggalan tersebut menggambarkan dan menerangkan aktivitas, tindakan, atau perilaku manusia dalam hubungannya dengan dirinya, manusia yang lain, dan/atau dengan yang maha manusia.

Hanif, M.(2010) menyebutkan beberapa situs sejarah di wilayah Madiun yang menjadi perhatian banyak orang diantaranya Prasasti Mruwak, Prasasti Klagen Serut dan Patung Dewi Sri, Candi Wonorejo, Kelompok Arca Mejayan, Situs Ngurawan, Situs Reksogati, Situs Mangiran, Sendang Kuncen, Makam dan Masjid Kuno Kuncen, Makam dan Masjid Kuno Taman, Pesarean Agung Kuncen Mejayan, Masjid dan Makam Ki Ageng Basyariah, Markas TRIP, Monumen Kresek, dan lain sebagainya. Seiring meningkatnya kegiatan masyarakat untuk traveling, berwisata, studi wisata, dan berpetualangan alam, situs-situs sejarah Madiun menjadi daya tarik tersendiri. Situs-situs sejarah Madiun kini menjadi salah satu destinasi wisata yang diminati untuk dikunjungi. Pengunjung tidak hanya datang dari masyarakat umum tetapi ada juga dari kalangan pelajar-mahasiswa, akademisi, peneliti dan lain sebagainya. Keanekaragaman latar tersebut ternyata memiliki motivasi dan tujuan yang juga bermacam-macam. Apapun motivasi dan tujuannya, para pengunjung yang datang di situs sejarah hampir dapat dipastikan ada keingintahuan cerita di balik peninggalan sejarah. Untuk itu kehadiran juru pelihara situs sejarah sangatlah penting.

Berdasarkan Undang-Undang Republik Indonesia Nomor 11 Tahun 2010 Pasal 62 tentang Cagar Budaya, juru pelihara memliki tugas untuk menjaga, melestarikan dan merawat situs. Menurut undang-undang tersebut, Pemerintah Pusat dan Pemerintah Daerah dapat mengangkat atau menempatkan juru pelihara untuk melakukan perawatan cagar budaya termasuk situs sejarah. Hal ini penting dilakukan karena situs sejarah memiliki makna strategis dalam membangun kesadaran sejarah dan identitas nasional.

Walaupun begitu ada sebagian masyarakat yang peduli, merawat, melindungi, dan melestarikan dengan menjadi juru kunci. Juru kunci tidaklah sama dengan juru pelihara walaupun ada beberapa hal yang sama dalam tugas dan pekerjaan. Namun realitanya di lapangan seringkali dipadankan, bahkan para juru pelihara dan kunci sering kali dijadikan informan, tempat bertanya para pengunjung terhadap situs yang dipeliharanya. Sehingga juru pelihara dan juru kunci situs memiliki peran strategis dalam penyampaian pesan kepada khalayak karena juru pelihara sering berhadapan langsung dengan pengunjung situs yang ingin mendapatkan informasi berkaitan dengan situs yang dijaganya.

Tidak sedikit juru pelihara dan juru kunci yang tidak mendalami secara ilmiah terhadap situs yang dijaga dan dipeliharanya. Mereka mendapatkan informasi dari mulut ke mulut dan cerita warisan, sehingga cerita yang disampaikan selalu dibumbui hal-hal bersifat magis. Hal tersebut tentu menyulitkan dalam pembedaan antara fakta dan fiksi.

Menerangkan atau menyampaikan informasi situs sejarah pada hakekatnya adalah menerangkan peristiwa dibalik peninggalanpeninggalan masa lalu yang berada di situs. Peninggalan tersebut merupakan salah satu bukti telah terjadi peristiwa atau segala sesuatu yang berkaitan dengan aktivitas hidup dan kehidupan manusia. Dalam ruang lingkup segala sesuatu yang telah dialami oleh manusia di masa lampau yang bukti-buktinya masih dapat ditelusuri/diketemukan di masa sekarang inilah yang diceritakan. Sedangkan kejadian atau peristiwa masa lalu yang tidak meninggalkan jejak atau bukti dianggap tidak pernah terjadi peristiwa atau fiktif (Widja, 1988).

Selain itu, ada sebagian para juru yang kemampuan berceritanya tergolong kurang sehingga menjenuhkan dan membosankan. Akibatnya pengunjung tidak terkesan, kurang puas, dan bisa tersesat pikiran dan pengetahuannya. Oleh karena itu perlu solusi alternatifnya salah satunya dengan latihan keterampilan dengan metode bercerita berpasangan.

Metode bercerita berpasangan bermula dari sebuah metode pembelajaran interaktif antara pihak pembelajar, pihak yang belajar, dan bahan pelajaran (Lie,2010). Metode ini dilandasi teori belajar konstruktivisme. Santrock (2010) menyampaikan bahwa pihak yang belajar dapat belajar dengan baik apabila mereka secara aktif mengkonstruksi pengetahuan dan pemahamannya. Dalam kaitannya dengan cerita situs sejarah, metode bercerita berpasangan menuntut para juru pelihara sebagai pihak pembelajar, para wisatawan sebagai pebelajar, dan cerita situs sejarah sebagai bahan pelajaran.

Metode ini merangsang para juru pelihara situs untuk mengembangkan kemampuan berpikir dan kemampuan berimajinasi. Hasil pemikiran juru pelihara akan 
dihargai, sehingga mereka merasa makin terdorong untuk belajar. Selain itu, juru pelihara situs dapat bekerja sama dengan juru pelihara situs lainnya dalam suasana gotong royong dan mempunyai banyak kesempatan untuk meningkatkan kemampuan bercerita atau menyampaikan informasi tentang situs yang dijaganya secara ilmiah, komunikatif, dan menarik.

Tujuan kegiatan ini adalah untuk meningkatkan keterampilan para juru pelihara situs dalam bercerita tentang situs sejarah yang dipeliharanya.

Kegiatan bercerita sejarah bagi para juru pelihara (termasuk juru kunci) merupakan kegiatan terprogram. Kegiatannya meliputi; (1) Sosialisasi program, (2) Pengayakan situs-situs peninggalan sejarah Madiun, (3) Pendalaman teknik bercerita secara ilmiah dan menarik, (4) Pembagian para juru pelihara situs kedalam 2 kelompok, (5) Juru pelihara diminta mengkaji situs sejarah yang dipeliharanya, (6) Juru pelihara situs kelompok satu bertemu dan saling berpasangan dengan juru pelihara situs kelompok dua untuk saling tukar informasi dan saling menjelaskan tentang situs-situs yang didalaminya, (7) Setelah seluruh juru pelihara situs selesai melakukan pertukaran informasi, maka selanjutnya perwakilan dari masingmasing kelompok juru pelihara situs untuk menceritakan kembali informasi yang diperoleh dari pasangannya di depan seluruh juru pelihara situs, (8) Penarikan kesimpulan tentang situs-situs peninggalan sejarah kabupaten Madiun.

\section{HASIL DAN PEMBAHASAN}

Pelaksanaan metode bercerita berpasangan bagi juru pelihara situs adalah sebagai berikut.

1. Juru pelihara situs dibagi 2 kelompok. Kelompok satu diberi bahan atau pendalaman situs-situs kelompok pertama. Juru pelihara situs kelompok dua diberi bahan atau pendalaman situs-situs kelompok kedua,

2. Juru pelihara diminta mengkaji literasi, mengamati, mencatat tentang situssitus yang didalami dalam kelompok awal,

3. Juru pelihara situs kelompok satu bertemu dan saling berpasangan dengan juru pelihara situs kelompok dua untuk saling tukar informasi dan saling menjelaskan tentang situs-situs yang didalaminya,

Setelah seluruh juru pelihara situs selesai melakukan pertukaran informasi, maka tim PKMS menunjuk 2 orang juru pelihara dari masing-masing kelompok untuk menceritakan kembali informasi yang diperoleh dari pasangannya di depan seluruh juru pelihara situs.

Adapun sintak penerapan metode bercerita berpasangan untuk meningkatkan keterampilan juru pelihara situs dalam bercerita sejarah sebagai berikut

1. Pendahuluan

a. Tim PKMS membagi materi situs sejarah Madiun menjadi dua bagian

b. Tim PKMS memberi penjelasan mengenai teknik bercerita dan situs sejarah Madiun

c. Para juru pelihara situs diminta perpasangan

2. Kegiatan inti

a. Juru pelihara situs kelompok satu diberi bahan atau pendalaman situssitus kelompok pertama. Juru pelihara situs kelompok dua diberi bahan atau pendalaman situs-situs kelompok kedua.

b. Juru pelihara diminta mengkaji, mengamati, mencatat tentang situssitus yang didalami dalam kelompok awal. Keterangan situs peninggalan sejarah terutama menjawab pertanyaan dari $5 \mathrm{~W}$ dan $1 \mathrm{H}$ yaitu What (wujud peristiwa), Who (pelakunya), Where (tempat terjadinya peristiwa), When (waktu Kejadian), Why (unsur mengapa/latar belakang terjadinya peristiwa), dan How (bagaimana mungkin peristiwa itu terjadi).

c. Juru pelihara situs kelompok satu bertemu dan saling berpasangan dengan juru pelihara situs kelompok dua untuk saling tukar informasi dan saling menjelaskan tentang situs-situs yang didalaminya.

d. Setelah seluruh juru pelihara situs selesai melakukan pertukaran informasi, maka tim PKMS menunjuk 2 orang juru pelihara dari masingmasing kelompok untuk

menceritakan kembali informasi yang diperoleh dari pasangannya di depan seluruh juru pelihara situs.

3. Kegiatan penutup

Tim PKMS bersama para juru pelihara situs sejarah Madiun menarik atau membuat kesimpulan tentang situs-situs sejarah Madiun. 


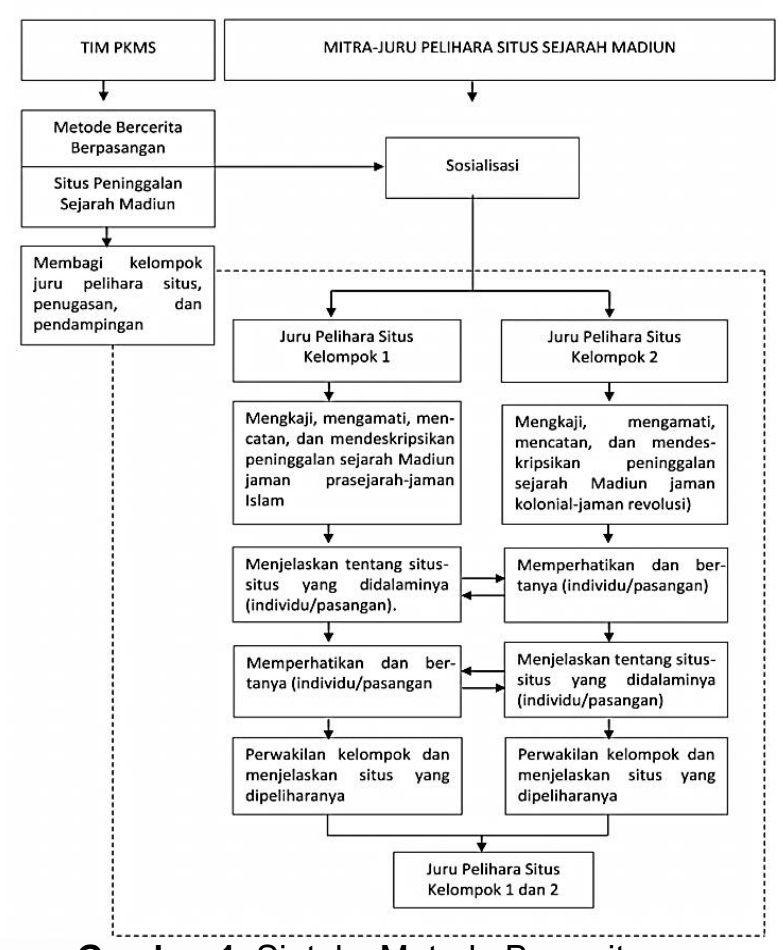

Gambar 1. Sintaks Metode Bercerita Bepasangan Bagi Juru Pelihara Situs Sejarah

Penilaian keterampilan para juru pelihara situs sejarah di Madiun dilakukan melalui unjuk kerja atau bercerita tentang situs yang dijaga/dipelihara. Penilaian dilakukan ketika juru pelihara belum diberi perlakuan dan sesudah diberi perlakuan dengan metode bercerita perpasangan, dan juga praktik di lapangan atau di situs yang dijaganya. Adapun komponen penilaiannya meliputi; kebenaran cerita (kebenaran koherensi, korespondensi, dan koherensi-korespondensi), kedetailan cerita (jika keterangan situs sudah lengkap), keruntutan cerita (plot), ketepatan kalimat, dan kekreatifan menghidupkan suasana. Adapun hasil penilaiannya sebagai berikut.

Tabel 1. Resume Evaluasi Keterampilan

Bercerita Para Juru Pelihara Situs Sejarah Madiun

\begin{tabular}{llllll}
\hline No & $\begin{array}{c}\text { Nama } \\
\text { Juru } \\
\text { Pelihara }\end{array}$ & Sesi 1 & Sesi 2 & Sesi 3 & Rerata \\
\hline 1. & Jupel 1 & 40 & 60 & 80 & 60 \\
2. & Jupel 2 & 45 & 65 & 85 & 65 \\
3. & Jupel 3 & 40 & 65 & 90 & 65 \\
4. & Jupel 4 & 50 & 70 & 90 & 70 \\
5. & Jupel 5 & 45 & 60 & 75 & 60 \\
6. & Jupel 6 & 50 & 65 & 80 & 65 \\
7. & Jupel 7 & 55 & 70 & 85 & 70 \\
8. & Jupel 8 & 45 & 65 & 85 & 65 \\
9. & Jupel 9 & 35 & 50 & 80 & 55 \\
10. & Jupel 10 & 50 & 60 & 70 & 60 \\
11. & Jupel 11 & 45 & 60 & 75 & 60 \\
\hline Jumlah Rerata & $\mathbf{4 5}$ & $\mathbf{6 2}$ & $\mathbf{8 1}$ & $\mathbf{6 3}$ \\
\hline
\end{tabular}

Sumber: Hasil observasi pelatihan

Berdasarkan tabel di atas, peningkatan keterampilan berceritas sejarah para juru pelihara situs sejarah Madiun dapat digambarkan dalam diagram di bawah ini.

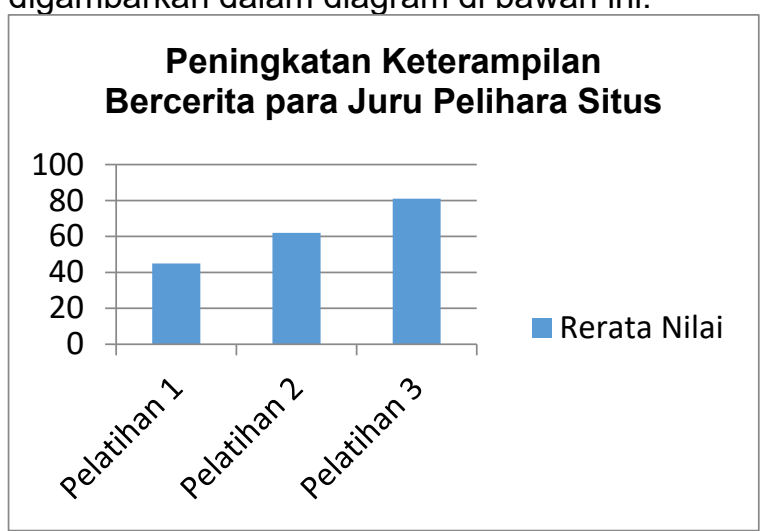

Sumber: Hasil evaluasi pelatihan

Gambar 1. Peningkatan Keterampilan Berceritas Sejarah para Juru Pelihara Situs Sejarah Madiun

Adapun grafik peningkatan keterampilan berceritas sejarah para juru pelihara situs sejarah Madiun adalah sebagai berikut.

\section{Peningkatan Keterampilan Bercerita para Juru Pelihara Situs}

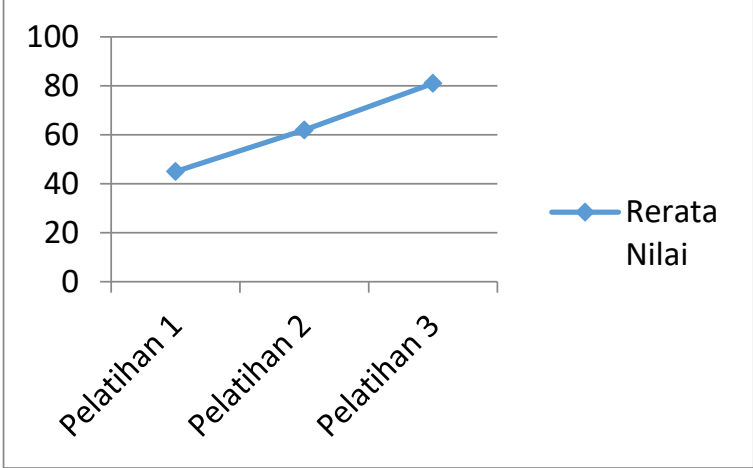

Sumber: Hasil evaluasi pelatihan

Gambar 2. Peningkatan Keterampilan Berceritas Sejarah para Juru Pelihara Situs Sejarah Madiun

Dari ketiga sajian data di atas, dapat diketahui peningkatan keterampilan bercerita para juru pelihara tentang situs sejarah Madiun dalam setiap kali pelatihan. Hasil evaluasi pada pelatihan 1 didapatkan keterampilan yang cukup rendah. Berdasarkan hasil rubrik penilaian, pada aspek pertama, yakni aspek kebenaran cerita (kebenaran koherensi, korespondensi, dan koherensi-korespondensi), para juru pelihara bercerita tidak berdasarkan bukti-bukti yang kuat dan lengkap (hasil riset, dan pendapat para ahli). Selanjutnya pada aspek Kedetailan cerita (Jika keterangan situs 
sudah lengkap), cerita yang disampaikan para juru pelihara tidak detail (menjawab pertanyaan $5 \mathrm{~W}+1 \mathrm{H}$ ) baik dari segi latar sejarah dan struktur rangkaian kejadian. Pada aspek Keruntutan cerita (plot), cerita yang disampaikan para juru pelihara tidak runtut (loncat-loncat). Dalam aspek ketepatan kalimat, para juru pelihara dalam bercerita tidak mengandung unsur kalimat yang tepat dan bahasanya sulit dipahami, serta diksinya tidak tepat. Pada aspek terakhir, yaitu kekreatifan menghidupkan suasana, para juru pelihara tidak mengembangkan humor di sela-sela bercerita, tidak melibatkan pengunjung situs dalam bercerita melalui pertanyaan, dan tidak melakukan improvisasi dan berolah suara, dan mimik.

Hasil evaluasi pada pelatihan 2 didapatkan keterampilan yang sudah meningkat disbanding pada pelatihan 1 . Berdasarkan hasil rubrik penilaian, pada aspek pertama, yakni aspek kebenaran cerita (kebenaran koherensi, korespondensi, dan koherensi-korespondensi), para juru pelihara bercerita berdasarkan sedikit bukti yang kuat dan tidak lengkap (hasil riset, dan pendapat para ahli). Selanjutnya pada aspek kedetailan cerita (Jika keterangan situs sudah lengkap), cerita yang disampaikan para juru pelihara tidak detail (menjawab pertanyaan $5 \mathrm{~W}+1 \mathrm{H}$ ) baik dari segi latar sejarah dan struktur rangkaian kejadian. Pada aspek Keruntutan cerita (plot), cerita yang disampaikan para juru pelihara sudah runtut namun ada beberapa bagian yang terlewatkan. Dalam aspek Ketepatan kalimat, para juru pelihara dalam bercerita mengandung unsur kalimat yang tepat dan bahasanya sulit dipahami, serta diksinya tidak tepat. Pada aspek terakhir, yaitu kekreatifan menghidupkan suasana, para juru pelihara mengembangkan humor di sela-sela bercerita, tidak melibatkan pengunjung situs dalam bercerita melalui pertanyaan, dan tidak melakukan improvisasi dan berolah suara, dan mimik.

Hasil evaluasi pada pelatihan 3 didapatkan keterampilan yang sudah meningkat disbanding pada pelatihan 1 dan 2 . Berdasarkan hasil rubrik penilaian, pada aspek pertama, yakni aspek kebenaran cerita (kebenaran koherensi, korespondensi, dan koherensi-korespondensi), para juru pelihara bercerita berdasarkan bukti-bukti yang kuat namun tidak lengkap (hasil riset, dan pendapat para ahli). Selanjutnya pada aspek kedetailan cerita (Jika keterangan situs sudah lengkap), cerita yang disampaikan para juru pelihara sudah detail (menjawab pertanyaan $5 \mathrm{~W}+1 \mathrm{H}$ ) baik dari segi latar sejarah dan struktur rangkaian kejadian. Pada aspek Keruntutan cerita (plot), cerita yang disampaikan para juru pelihara sudah runtut (dimulai dari awal sampai sekarang atau sekarang ke awal). Dalam aspek Ketepatan kalimat, para juru pelihara dalam bercerita mengandung unsur kalimat yang tepat dan bahasanya mudah dipahami, walau terkadang ada pemilihan diksi yang kurang tepat. Pada aspek terakhir, yaitu kekreatifan menghidupkan suasana, para juru pelihara mengembangkan humor di sela-sela bercerita, sudah melibatkan pengunjung situs dalam bercerita melalui pertanyaan, namun belum melakukan improvisasi dan berolah suara, dan mimik.

\section{SIMPULAN DAN SARAN}

Berdasarkan analisis di atas, dapat disimpulkan bahwa keterampilan bercerita para juru pelihara tentang situs sejarah Madiun meningkat setelah mendapatkan pelatihan berupa metode bercerita berpasangan. Peningkatan keterampilan pada setiap aspek cukup signifikan. Peningkatan keterampilan kelima aspek pada pelatihan 1 didapatkan nilai rata-rata sebesar 45 , kemudian meningkat menjadi 62 pada sesi pelatihan kedua, dan pada pelatihan ketiga meningkat lagi menjadi 81. Peningkatan tersebut seharusnya dapat terus dipertahankan dan ditingkatkan lagi. Jika juru pelihara situs sejarah menyuguhkan sikap yang responsif, baik, bercerita secara benar dan menarik maka akan banyak pengunjung yang terkesan, terkenang, dan menjadikannya sebagai edukasi, inspirasi, dan rekreasi.

\section{UCAPAN TERIMAKASIH}

yang terhormat:

Kami sampaikan terima kasih kepada

1. Direktur Riset dan Pengabdian Masyarakat Kementerian Riset dan Teknologi Rebublik Indonesia

2. Diputi Bidang Penguatan Riset dan Pengembangan Kementerian Riset dan Teknologi Indonesia

3. Kepala LLDIKTI Wilayah VII Jawa Timur

4. Rektor Universitas PGRI Madiun

5. Kepala LPPM Universitas PGRI Madiun beserta staf

6. Para juru pelihara cagar budaya dan juru kunci situs sejarah Kabupaten Madiun dan Kota Madiun

7. Para pihak yang telah berkonstribusi pada buku ini yang tidak kami sebut satu persatu.

\section{DAFTAR RUJUKAN}

Alderson, W.T., \& Low, S. P. (1996). Interpretation of Historic Sites. Altamira Press. 
Hanif, M., D. (2010). Pemetaan Peninggalan Sejarah Kabupaten Madiun Guna Meningkatkan Industri Pariwisata Budaya.

Haviland, W. A. (1985). Antropologi (R.G. Soekadijo (ed.); 4th ed.). Airlangga.

Suroto, H. (2020). Apa Situs Arkeologi.

Widja, I. G. (1988). Pengantar IImu Sejarah, Sejarah Dalam Perspektif Pendidikan. Satya Wacana. 